\title{
Accounting Teacher Professional Identity Framework: A Blended Concept of Accountant and Teacher Professionalism
}

\author{
Muhammad Fahmi Johan Syah ${ }^{1, *}$, Sharul Effendy Janudin², Mahaliza Mansor ${ }^{3}$, Harsono ${ }^{1}$ \\ ${ }^{1}$ Department of Accounting Education, Faculty of Teacher Training and Education, Universitas Muhammadiyah Surakarta, Indonesia \\ ${ }^{2}$ Department of Accounting and Finance, Faculty of Management and Economics, Universiti Pendidikan Sultan Idris, 35900 Tanjung \\ Malim, Perak, Malaysia \\ ${ }^{3}$ Department of Educational Management, Faculty of Management and Economics, Universiti Pendidikan Sultan Idris, 35900 Tanjung \\ Malim, Malaysia
}

Received September 1, 2020; Revised October 30, 2020; Accepted November 19, 2020

\section{Cite This Paper in the following Citation Styles}

(a): [1] Muhammad Fahmi Johan Syah, Sharul Effendy Janudin, Mahaliza Mansor, Harsono , "Accounting Teacher Professional Identity Framework: A Blended Concept of Accountant and Teacher Professionalism," Universal Journal of Educational Research, Vol. 8, No. 12A, pp. 7367 - 7378, 2020. DOI: 10.13189/ujer.2020.082521.

(b): Muhammad Fahmi Johan Syah, Sharul Effendy Janudin, Mahaliza Mansor, Harsono (2020). Accounting Teacher Professional Identity Framework: A Blended Concept of Accountant and Teacher Professionalism. Universal Journal of Educational Research, 8(12A), 7367 - 7378. DOI: 10.13189/ujer.2020.082521.

Copyright $\odot 2020$ by authors, all rights reserved. Authors agree that this article remains permanently open access under the terms of the Creative Commons Attribution License 4.0 International License

\begin{abstract}
This systematic literature review paper explores the importance of embedding accounting teachers' professional identity concept in the Indonesian education system particularly in teacher education. The Indonesian government is still struggling to enhance teacher professionalism; thus, many training pieces have been developed to overcome teachers' low quality. However, the teacher's competency in Indonesia is still behind the other countries implied in the PISA score, indicating a missing link in teacher education. The professional identity has attracted scholars in various fields to define the meaning of professional identity and develop it in an individual. The particular definition of accounting teacher professional identity is still not studied. Therefore, exploring previous studies in professional identity to identify teacher professional identity is needed. In the accounting teacher context, the paper proposes to combine two professional identity formations from teacher and accountant. By reviewing both fields, the concept of accounting professional identity and the development is drawn. This paper will discuss accounting teachers' identity that may be a new solution for the teacher education program, especially in accounting. In short, developing professional identity in accounting teachers needs to be done in three stages (pre-service, beginner, and experienced teachers).
\end{abstract}

Every step has unique identities, but all phases need community involvement to ensure professional identity is formatted.

Keywords Accounting, Teacher, Professional Identity, Indonesia

\section{Introduction}

Teacher professional development is broadly studied and defined by many researchers and practitioners in education. Even the educational system tries to develop the teacher professional development since the students enter the teacher candidate program in university as pre-service teachers [1]. The teacher professional development is defined as any activity partly or primarily to enhance teachers' instructional practice and professionalism [2]. On the other hand, professional development cannot leave job taxonomy, where people in work have in-role behavior and extra-role behaviors [3]. Thus, in using the term of professional development, the research defines it as any program to increase teachers' ability and capability to do their work both in-role and extra-role behaviors so that the 
quality of human resources is more competitive. Teacher professional development is a critical aspect to upgrade the skill of instructional practice for teachers, increasing the students' learning outcome [2].

The teacher professional development is mainly discussing teacher performance in their instructional practice, both in-role and extra-role behaviors. The in-role behavior is the core-task that must be fulfilled as a worker [3], while extra-role behavior must be voluntary [4]. In this context, teacher's in-role behaviors are those obligations that are stated in Indonesian law number 14 of 2005 [5] concerning teachers and lecturers. One of the articles says that a teacher in Indonesia is defined as a professional educator with the main tasks to educate, teach, guide, direct, train, assess, and evaluate students on early childhood pathways in formal education, basic education, and secondary education. At the same time, extra-role behaviors are included in the social and personality competencies of teachers.

The various types of teacher professional development have been developed. Firstly, the teacher agency, the complex and multifaced concept in teacher development, aims at escalating teacher professionalism through adopting innovative and questioning mindset, which lead to instructional change [6]. This method emphasizes on how teachers can be a collegial discussion partner in various ways. Secondly, arranging an online community of teachers to develop professionalism. For example, the development of Massive Open Online Courses (MOOCs) in Kenya has a positive impact on teacher professionalism because of the high quality of the process [73]. The rapid change in information technology allows a teacher to be an active learner and co-creator content. This way boosts teachers' engagement [7], where engagement is an essential factor for teacher performance [8]. Thirdly, in Indonesia, the government runs a blended learning program, namely Pendidikan Profesi Guru (Teacher Profession Education) PPG, to develop professional teachers.

Despite many teacher professional development approaches have been developed and implemented in Indonesia, teacher professionalism in Indonesia is still a critical issue even though the quality of teachers is improving [9]. According to the data from the education ministry of Indonesia, the teacher's quality is still below the average 71,41 , which is considered that they have low competency (The Centre of Data and Statistic, Education Ministry of Indonesia, 2016). In some cases, there is a missing link between teacher professional development and teacher motivation on implementing the knowledge to the practice [2]. In contrast, long-term professional development has a less sustained impact on well-being and practice [10]. This condition indicates that there is a missing link between the professional development process and output. The teacher's competencies such as professional, pedagogy, social, and personality positively impact students' achievement and curiosity [11], [12]. The teacher quality can be seen in the Programme for International Student Assessment (PISA) result, which indicates the student skills in reading, mathematics, and science are below the average. The result of PISA is below:

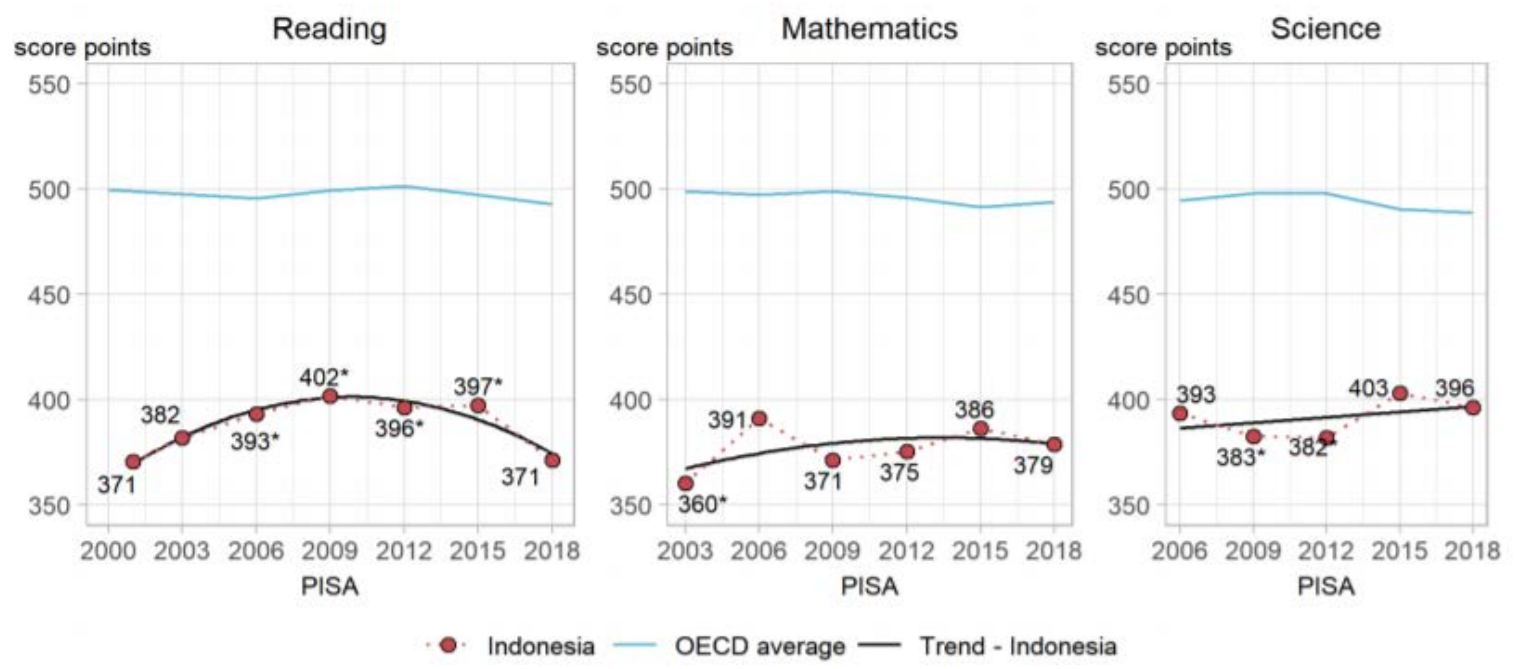

Figure 1. PISA Result 2018 
The Indonesian education system may neglect the importance of the teacher's professional identity in a professional teacher's development program. Identity means an explicit response to the question "who am I" [13]. The professional identity itself is evolving, which requests not only in a professional manner in job tasks but also in a personal way [14]. In addition, an individual has multiple identities so that the capability of maintaining the identity is critical. For example, an accounting teacher has identities as an accounting teacher, colleague, co-worker, and also his/her identity in the society such as a husband/wife, father/mother, and many other characters. The development of teacher professional identity itself involves evolution from teacher-students, beginner teachers, and experienced teachers (Hong, 2010).

The study of professional identity has been conducted in several occupations such as medical, police officers, and teachers [16], [17]. Nyström (2009) explains that professional identity is shaped in the dynamic process in the teacher's personal life and work experiences. In terms of teachers, the studies on mathematic, English, and music teachers interestingly proceed findings. Developing a new environment on learning mathematic is a kind of mathematic teacher's professional identity [19]. The different findings are stated for English teachers. Overcoming English learning obstacles, having the capability to act as an artist, and joining in several communities are the essential professional identity of them [20]-[22]. On the other hand, a music teacher should be a musician named a professional [23].

Those studies imply that the professional identity may be unique between teachers based on the subject teachers even though it might be stated as professional identities for all teachers. For example, all teachers should join a community, but not all teachers should be able to act as an artist or musician. Therefore, there is not only possible to identify the professional identity as general for all teachers but also the specific identity on subject teachers should be observed.

Unfortunately, the current studies indicate that professional identity is not stated for all field teachers. The accounting education itself has particular culture such as academic competitiveness, a strong sense of belongingness, positive elements, and negative elements [74]. The accounting teacher professional identity studies are rare even not studied by scholars, including in Indonesia. This may be one of solution for enhancing accounting teacher professionalism in Indonesia. For a broader impact, it might be suitable to be implemented in the whole Indonesian education system.

Based on Indonesian law number 14 of 2005, teachers are obligated to have four minimum competencies, namely pedagogy, professional, social, and personality. The elucidation of this law in article 10 explains the meaning of those competencies. First of all, pedagogy competency means the ability of the teacher to manage students' learning process. This is related to how teachers as a director in a classroom to gain the students' learning outcome. Secondly, professional competency is the teacher mastery in the learning material. For example, the accounting teacher should fully understand all the accounting material. Thirdly, social competency is the teachers' capability in building effective communication with students, co-workers, parents, and society. They are not only obligated to have good relationships with students but also with all school stakeholders. Lastly, personal competency refers to teachers should have a great personality, noble morals, wisdom, authority, and be a model for students.

These competencies are obligated to all teachers in Indonesia without regard to the subject of the teachers. Accounting teachers' competencies are not stated so that it might be a misleading concept when the government tries to enhance accounting teacher professionalism. It should be different from the professionalism meaning in accounting teachers with other subject teachers.

Furthermore, the present studies indicate that the accounting teachers in Indonesia need to be strengthened in their competency. They are lack of professionalism [24] and have low competency mastery [25]. It may be one of the causing factors of high unemployment from accounting vocational school graduates [26].

This paper will discuss how the accounting professional identity is a matter for accounting teacher educational system. Overcoming the education issue in Indonesia is critical so that considering a new framework can be a new concern for practitioners. Even though numerous methods have been taken to improve teacher competencies, in fact, the quality of Indonesian teachers is still questioned both by the government and scholars. This study focuses on the accounting professional identity that may improve the quality of accounting teachers in Indonesia. The conceptual review will be conducted based on the professional identity theories and previous studies, professional development theories and studies, and also the characteristic of Indonesian accounting teacher.

\section{Literature Review}

\subsection{The Definition of Professional Identity}

The understanding of professional identity attracts scholars because of its sophisticated [16], [17]. The most challenging issue is the clarity of the meaning of identity [27] and also teacher identity [28]. Furthermore, the unique essence of identity is rarely found in the literature [29]. The researcher who is interested in this field always tries to find out the actual meaning of the identity, which indicates that the concept of identity needs to be more explored and redefined based on the context.

The understanding of professionalism and identity can 
explore the definition of professional identity. Professionalism means a public recognition group having a specific skill, standards of knowledge obtained by education, training, and research [30]. It means that professionalism is not a self-claim by the individual; it is embedded by the society to admit that a person is a professional one. However, to define identity is not simply constructed. It is sometimes hard to be understood [31], [32]. In short, professional identity means how an individual perceives occupational context and how we communicate this to others [33].

\subsection{The Professional Identity Theory}

Generally, the studies in this field consist of several objectives namely, constructing definition, characteristics identification, teacher's representation [31], developing scale [34], the effect on performance [35], and other particular studies. At the beginning of professional identity studies, the scholars genuinely construct the meaning of professional identity by reviewing the root theory of identity. However, some studies cannot clearly state the definition of this construct [31]. After the growth of professional identity studies by using a qualitative approach, other studies try to measure professional identity as a measurable construct by designing scale and test the validity and reliability. The developed scale inspires researchers in a quantitative approach to relating this construct to other constructs such as performance on students, teachers, and employees.

Constructing the rationale of the identity needs to explore the root of the theories that underlies the construct. The traditional and structural symbolic interactionism theory; and role theory are essential to developing the identity theory. Stryker (2002) explains that traditional symbolic interactionism theory focuses on some imageries of the human being; one of them is human action and interaction. In this theory, an individual utilizes the symbolic of developing interaction and communicating those symbols in the society while society is the summary of the interaction. While in the structural symbolic interactionism theory, there are seven main ideas namely 1) human experience is socially organized, 2) social life is constructed, 3) human being are actors, 4) the subjective and the symbolic are the central in social life, 5) self mediates the relation of society to social behavior and social behavior to society, 6) there is both constraint and freedom in personal and social life, 7) the concept of role facilitates the articulation of symbolic interactionist and role theory ideas. Lastly, in the role theory, group member (individual) performance is affected by group norms as a result of the interaction as a human being.

From those three theories, the identity theory grows. Burke \& Jan E. Stets P, (2009) emphasizes some theories from Stryker, George McCall, and J.L Simmons, and his works with the colleague to arrange the identity theory. The identity is constructed by four main components, namely an input, an identity standard, a comparator, and an output [37]. All components are interconnected that bring the individual to have an identity and be admitted by the society members.

Based on the developed identity theory, the scholars try to find the characteristic of professional identity in a particular occupation, including in the teacher. In the teacher, the identification of characteristic or formation is related to in-role and extra-role behavior in the workplace. A teacher can shape his/her professional identity through expanding the experience, intensifying classroom interaction effectively and efficiently, and broadening community involvement [38].

\subsection{Teacher Professional Identity}

The development of the professional identity of the teacher starts in the university as pre-service teachers. The first-year program composition in university really matters on construction in the student-teachers' professional identity in terms of repositioning, shifting identities, and new understanding in teaching [39]. The new students may feel that the university learning climate is different from the senior high school climate. This shifting is a gap that must be filled by the education policy in preparing professional new teacher candidates.

The activeness of student-teacher in the university can shape the professional identity among pre-service teachers [40]. In addition, the development of professional identity among student-teachers is related to how they perceive the learning to teach in the training program [41]. Some scholars also consider the importance of an experienced teacher role in shaping newcomers' professional identity [42].

The new teachers express identity shifting when entering school. They suffer the contradiction between the idealism of knowledge and realism in school practice [19]. Thus, the development of professional identity in the early career of the teacher is challenging. Therefore, the mentoring method from the experienced teachers to newcomers is essential to develop a professional identity on beginner [22] by using several techniques such as dialogue [43], [44] and positioning [45], team teaching [46]. Those methods are positively related to professional identity development and overcome the obstacle condition for new teachers.

The numerous studies in professional identity construction trigger the scholars to put the professional identity as a measurable construct. First of all, the research starts to test the manifest variables of professional identity. The structural model of the teacher's professional identity consists of six latent variables, namely self-expectation, teacher duties, influential external factors, pedagogy, instructional skill and knowledge, and citizenship behavior [47]. Furthermore, the researcher also discusses the validity and reliability of the questionnaire [48]. 
Lentillon-Kaestner et al., (2018) develop The Questionnaire on Perceived Professional Identity among Teachers (QIPPE). Hanna, Oostdam, Severiens, \& Zijlstra, (2019) conduct research that creates and validates the professional identity tension scale for pre-service teachers.

By using the developed scale for a particular occupation, the scholars are interested in examining factors that affect professional identity and the effect of this variable on other constructs. Professional identity is positively linked to task value belief, intrinsic and extrinsic learning motivation, and performance [50], [51]. The changes in the digital era also affect professional identity studies, which are considering the effect of blended learning on professional identity formation is remarkable [52]. Maintaining the identity means the teacher should have a feeling of "good teacher" as one of the teacher identities, which helps them to preserve their performance in the changing technology in teaching [53] and they need high self-efficacy [54].

\subsection{The Accounting Teacher Professional Development in Indonesia}

The Indonesian government attempts to foster professionalism in Indonesia by providing several programs and training. The obligations that stated in Indonesian law number 14 of 2005 concerning teachers and lecturers order teachers to have a professional certificate by entering a professional training. The program was education and training teacher profession (PLPG), which now is shifted to the education teacher profession (PPG). Furthermore, there are many pieces of training provided by the government and university to lift Indonesian teachers' professionalism.

Indonesian teachers should master in four competencies, namely pedagogy, professional, social, and personality. Pedagogy competency is the ability to arrange the learning climate in the classroom. Personality competence is a personality ability that is steady, noble, wise, and authoritative, as well as a role model for students. Professional competency is related to how teachers understand the material of the lesson. In the accounting teachers' context, professional competence consists of understanding the basic accounting, intermediate accounting, and manufacturing accounting besides tax and several related materials. Lastly, social competence is the ability of teachers to communicate and interact effectively and efficiently with students, fellow teachers, parents/guardians of students, and surrounding communities.

The effect of teacher certification through PLPG was assumed to enhance teacher professionalism significantly (Istiarini \& Sukanti, 2012) (Wahyudi, Thomas, \& Setiyani, 2012). However, in terms of accounting teachers, an audit of accounting teacher performance shows that mostly only low and medium competency [55]. Furthermore, based on the Indonesian Central Bureau of Statistics (BPS), the vocational schools' graduates contribute to $11,03 \%$ (13,6 million people) of unemployment in Indonesia (BPS, 2018).

\section{Method}

This is a systematic literature review study with a qualitative design. This study follows the routine literature review procedure by Harari, Parola, Hartwell, \& Riegelman (2020) that this study can follow both approaches qualitative and quantitative design. The method is database search, consisting of three categories: keyword search in electronic database, selecting the most suitable articles, and comparing the findings from selected articles. First, the keywords are Identity, Professional, Teachers, Accountant, and Identity Theory. The articles are restricted from 2000 - 2020 in consideration of novelty and the research finding. However, articles published in less than ten years take precedence. Whereas articles that are more than ten years old are selected only if the results presented are essential to this analysis. Secondly, the article's selection is made by reviewing the abstract, the highlight, and the body articles sequentially. Besides, we also search in complementary sources such as conference programs, official websites, and others. Thirdly, the finding comparison is a part of data analysis that compiles the theories and the findings of the most recent studies and is linked to the Indonesian accounting teacher professional identity context.

\section{Discussion}

\subsection{A Challenge in the Concept of Accountant Professional Identity}

Numerous past researches indicate the difficulty in the essence of identity comprehension so that the formulation of a professional identity concept attracts scholars to define and to redefine [16], [17]. Some studies explain that the identity concept is unclear, but the most important thing is that the identity conception is evolving [57]. However, it does not mean that it is naturally unstated, but it needs to be more explored.

The view of Stryker (2002) depicts that structural symbolic interactionism theory is a fruitful root theory of identity. This notion comes from the traditional symbolic interactionism and role theory. Reviewing these theories can be an essential way to comprehend what identity and professional identity are. As stated in the literature review, there are 7 points of this theory.

First of all, human experience is socially organized. Human is involved in contemporary societies such as role relationship, groups, social network, institution, strata, and many other forms of interaction. Furthermore, the personal experience is not run by nature but organized by a social structure that defines the boundaries in a person's life. 
Secondly, social life is constructed. It is a product of collective activities of people to overcome their life obstacles. Thus, the rapid change of events may occur to deal with the problems Thirdly, a human being as an actor. In this view, humans are active agents for their life, including actions and reactions regarding a particular situation faced to them. Fourthly, subjective and symbolic is central in social life. It means that the interpretation of a particular condition in social life determines the person's behavior. Fifthly, self mediates the correlation of society to social behavior and vice versa. How people define themselves has an impact on their interaction in the social relationship. Sixthly, there is both strict and loose in personal and social life. People are restricted in how they define who they are, can become, and do as the corollary as members of society. Lastly, the concept of facilities symbolic and theories role is essential. The main point in this part is what the people expect in the relationship in society.

Stryker (2002) proceeds the identity theory based on the structural symbolic interactionism. The main thing of identity theory is role-choice behavior in society. People have the freedom to choose their role but then are restricted when entering the community as a group member. This theory seeks to explain why and where the people's identity is chosen that may differ with other members. In short, there are some assumptions of identity theory in understanding identity. A person is an actor and reactor. Social interaction and structure affect people's behavior. Action and reaction are affected by the interpretation of interaction in community, and perception matters in shaping identity in a group. Last but not least, identities are internalized role expectations.

Table 1. Definitions of professional identity

\begin{tabular}{|c|c|c|c|}
\hline No & Authors & Field & $\begin{array}{c}\text { Professional Identity } \\
\text { Definitions }\end{array}$ \\
\hline 1 & {$[33]$} & $\begin{array}{c}\text { Career } \\
\text { Development }\end{array}$ & $\begin{array}{c}\text { The concept which describes } \\
\text { how people perceive } \\
\text { themselves within the } \\
\text { occupational context and } \\
\text { how people communicate } \\
\text { this to others }\end{array}$ \\
\hline 2 & {$[39]$} & $\begin{array}{c}\text { Teacher } \\
\text { Education }\end{array}$ & $\begin{array}{c}\text { A positive revolution in } \\
\text { teacher's behavior, beliefs, } \\
\text { values as an impact of social } \\
\text { interaction }\end{array}$ \\
\hline 3 & $\begin{array}{c}\text { (K. H. Guo, } \\
2018)\end{array}$ & $\begin{array}{c}\text { Accountant } \\
\text { Profession }\end{array}$ & $\begin{array}{c}\text { How individuals work in } \\
\text { terms of accounting in the } \\
\text { past, present, and future }\end{array}$ \\
\hline 4 & {$[46]$} & $\begin{array}{c}\text { Teacher } \\
\text { Education }\end{array}$ & $\begin{array}{c}\text { Assumptions and notions of } \\
\text { how should a teacher be and } \\
\text { his/her implicit theories of } \\
\text { teaching }\end{array}$ \\
\hline
\end{tabular}

By considering structural symbolic interactionism and identity theory, the experts in this field try to define the professional identity. The study in professional identity mostly focuses on three main aspects, namely professional identity formation (including definition), the characteristics, the identity, which is represented by personal experiences [31]. However, to research those topics, the precise definition of professional identity is needed. Table 1 shows some magnificent studies that define professional identity in several occupations.

In terms of accountant teacher professional identity, the study in this particular context is not stated yet. Therefore, the accounting teacher professional identity concept might be a combination of the teacher professional identity and accountant professional identity. The accountant teachers are obligated to understand both accounting and teaching. Thus, this study emphasizes the accountant professional identity, which consists of both an accountant and a teacher. Mirroring in both occupational contexts is essential to understand the concept of accountant teacher professional identity.

The accountant professional identity definition is constructed by considering the structural symbolic theory, identity theory, and previous professional identity studies in several occupations. Both theories state the person's role in society and his/her behavior in a community. Furthermore, previous studies imply that professional identity is positive behavior and thought description of professional life and social interaction. Based on those assumptions from theories and empirical studies, the accountant professional identity is how accountant teachers play a role in the teaching profession and accounting field, which includes their professional journey in understanding both identities (teacher and accountant) admitted by their communities.

\subsection{The Concept of Accounting Teacher Professional Identity Development}

Scholars have conducted a discussion of how to develop a professional identity in teachers in recent years. Mostly, the scholars seek to identify a training model to trigger teacher professional identity in pre-service teachers, beginning teachers, and experienced teachers. The treatments for three groups may differ from each other because of their characteristics. The identity review will be conducted in the framing of an accounting teacher professional identity development model.

The teacher professional identity development strategies need to review the identity process theory and identity theory that provide how the identity is shaped. Jaspal \& Breakwell (2014) explains the identity process theory assumption as to how social representations affected identity processes and how identity processes, in turn, shaped social representational processes. This notion implies that social interaction affects the process of identity development in a person. On the other hand, the identity theory assumption is an individual's self-concept that derives from his knowledge of his membership of a social group (or groups) and the value and emotional significance attached to that membership. The focus of identity theory notion is how individuals think about themselves as 
members of a group and resulting in behavior that may be accepted by group members.

Inspired by the Weiner (1948) idea, Burke \& Jan E. Stets $P$ (2009) provide the importance of the control system in the identity formation process. Below is the identity model that they produce:

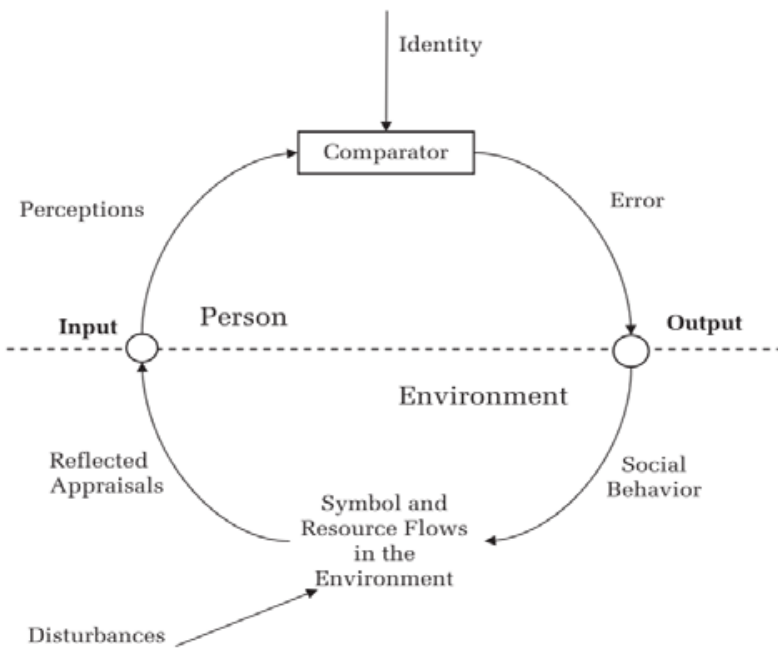

Figure 2. The Identity Model [37]

Figure 2 depicts the model of identity development in a person in the society consisting of four main aspects, namely identity standard, input, comparator, and output. The identity standard is a set of meanings that applies to the community. In other words, the identity standard means the expectation of society about a particular behavior. For example, as a man, a person should be strong, resourceful, and independent [37]. This set of meanings will be stored in a person's memory as standard as a man. The standard assesses the person's perception of the environment and what is happening around us. The perception in this context is an input for identity development. The comparison between input and standard is a process called comparison. The process will result in an error behavior if the input does not comply with the standard. Lastly, the output is the result of the dynamic process of input, standard, and comparator.

In the accounting teacher professional identity development context, the previous findings indicate three stages in teachers' career life: pre-service, early career, and experienced teachers. By considering the identity model as stated in figure 2, the development of accounting teachers' professional identity needs to assess teachers' perceptions about themselves and their perception of the peripheral situation, especially in the work environment and communities. The perception is as input for starting the development of professional identity. Accordingly, dealing with the perception analysis needs a valid scale to measure what perception the teachers should have before starting professional identity development.

By understanding the accounting teacher's thoughts, the next step identifies the standard of accounting teacher professional identity. The identity standard is constructed by considering Indonesian law number 14 of 2005, identity theories, previous findings on teacher professional identity standard, and accountant professional identity standard. As stated in article 10, Indonesian law number 14 of 2005, a teacher should have four competencies, namely pedagogy, personality, social, and professional. These four competencies are not negotiable for all Indonesian teachers. In terms of accounting teachers, this law only differs from the teacher's competency in the professional context, which is mastery in the subject material. For example, the accounting teacher and English teacher must have professional skills but different contents. Thus, this is not enough description for being a professional teacher if the term of professional identity is used. The identity theory model explains that the perception and the identity standard are matters to bring the process into the comparator and result in output.

However, the accounting professional identity standard is not stated in the Indonesian education system for accounting teachers. Thus, besides the standard for teacher competencies, as stated in Indonesian Law, reviewing teachers' professional identity conducted by previous studies is needed. Furthermore, the adoption of an accountant's professional identity is also prominent. These below some findings that are valuable for accounting professional identity standards in Indonesian context:

Table 2. The Pre-Service Teacher Professional Identity Development

\begin{tabular}{|c|c|}
\hline Authors & Findings \\
\hline [59] & $\begin{array}{l}\text { Clustering the basic capability in teaching for } \\
\text { undergraduate and graduate students should be } \\
\text { driven before running the professional } \\
\text { development identity in student-teacher }\end{array}$ \\
\hline [41] & $\begin{array}{l}\text { Developing professional identity in } \\
\text { student-teacher can be implemented in a paired } \\
\text { placement teaching practicum, especially in } \\
\text { students' multiple identities, namely as a friend, } \\
\text { student, and teacher training. }\end{array}$ \\
\hline [40] & $\begin{array}{l}\text { Those who act actively in the education process } \\
\text { will master professional identity better than } \\
\text { inactive participants }\end{array}$ \\
\hline [60] & $\begin{array}{l}\text { Reflexive and interactive positioning is } \\
\text { important to format professional identity in } \\
\text { pre-service teacher }\end{array}$ \\
\hline [61] & $\begin{array}{l}\text { Students' teacher professional identity is an } \\
\text { ongoing process, and the result depends on how } \\
\text { they involve in some activities that add their } \\
\text { experiences }\end{array}$ \\
\hline
\end{tabular}

Table 2 depicts some valuable findings in the pre-service teacher professional identity development. Those researchers indicate the professional identity is mostly shaped in training in school by positioning in some tasks. The participants imply to have multiple identities, such as a friend, students, and teacher training. The student role as a friend is both for their peers and to the students. Conversely, students may face student and teacher training identities when facing tutor teachers and students. The activeness in the training program is a bridge changing the identity from 
a student to a professional teacher.

Table 3. The Early Career Teacher Professional Identity Development

\begin{tabular}{|c|c|}
\hline Authors & Findings \\
\hline [62], [22] & $\begin{array}{l}\text { The professional identity among new teachers is } \\
\text { discursive because they develop many identities }\end{array}$ \\
\hline [63] & $\begin{array}{l}\text { The teacher's initial identities and providing } \\
\text { storytelling process are prominent for professional } \\
\text { identity development }\end{array}$ \\
\hline [64] & $\begin{array}{l}\text { In the early career of the teacher, the negative feeling } \\
\text { that the teacher felt about the material because of the } \\
\text { difficult material makes the teacher has more effort to } \\
\text { ensure students' comprehension in particular material }\end{array}$ \\
\hline [21] & $\begin{array}{l}\text { The anxiety in newcomer teachers bring identity } \\
\text { development is needed in different forms. Some } \\
\text { valuable actions are joining communities and } \\
\text { following structured and non-structured learning } \\
\text { opportunities }\end{array}$ \\
\hline [65] & $\begin{array}{l}\text { Professional identity in the early career teachers is } \\
\text { shifted by competition among them and is narrowed } \\
\text { to the school objectives and goals }\end{array}$ \\
\hline
\end{tabular}

Table 3 explains some professional identity development among newcomers. At the beginning of the career, teachers are shifting identity from students to teachers. This condition brings teachers to the anxiety and discursive situation. Thus, one of the most appropriate strategies is obligating them to join a professional community. By entering a group of professionals, they have the opportunity to share their stories and listen to the experiences of their colleagues. Besides, in this stage, they have a lot of energy to overcome some barriers in teaching so that they need assistance from the professional society.

Table 4. The Experienced Teacher Professional Identity Development

\begin{tabular}{|c|c|}
\hline Authors & \multicolumn{1}{c|}{ Findings } \\
\hline$[66]$ & $\begin{array}{c}\text { As experienced teachers, they should have roles as } \\
\text { manager, professional, and "acculturator" (assimilate } \\
\text { different conditions of the environment, teachers, and } \\
\text { others to ensure the quality of learning) }\end{array}$ \\
\hline$[20]$ & $\begin{array}{l}\text { Teacher identities in senior teachers are probably as } \\
\text { artists, mothers, trial judges, intercultural promoters and } \\
\text { democrats }\end{array}$ \\
\hline$[75]$ & $\begin{array}{l}\text { Those experienced teachers' identities are manager, } \\
\text { professional, and easily adapt and adjust many } \\
\text { different conditions on to reach the teaching objective, } \\
\text { and others that more individually identities }\end{array}$ \\
\hline
\end{tabular}

As experienced teachers, professional identity characteristics are different from pre-service and beginner teachers. A mature teacher should have a role as parents in school (mother or father), wise judges, promoters, and teaching by listening to students' opinions and accepting colleagues' advice. They should have the ability to decide something unhurriedly. Furthermore, they also have a role as manager, professional, and adaptive person.

Those findings can be adopted as a professional identity standard for teachers in Indonesia. However, researchers in Indonesia have not studied the teacher professional identity, particularly on accounting teachers. Therefore, absorbing from accountant professional identity can bridge this gap in professional identity for accounting teachers. Below are some studies in accountant professional identity:

Table 5. Accountant Professional Identity

\begin{tabular}{|c|c|}
\hline Authors & Findings \\
\hline [68] & $\begin{array}{c}\text { The involvement in professional community influences } \\
\text { accountant trainee in developing their professionalism } \\
\text { because of the interaction with the experienced } \\
\text { accountants }\end{array}$ \\
\hline [69] & $\begin{array}{c}\text { Group level identities influence individual accountant } \\
\text { professional identity in the accountant profession. The } \\
\text { role accountant profession association is prominent in } \\
\text { shaping the junior accountant. }\end{array}$ \\
\hline [70] & $\begin{array}{c}\text { Public perception of the accountant profession forces } \\
\text { them to do some strategies such as playing drama and } \\
\text { holding the idealism. It can forecast their professional } \\
\text { identity. }\end{array}$ \\
\hline [71] & $\begin{array}{c}\text { The accountant multiple identities are a career, a } \\
\text { problem solver, and an identity named "fix-it." } \\
\text { However, the term "fix-it" can be vulnerable to data } \\
\text { manipulation. The accountant should be } \\
\text { straightforward and honest in all professional and } \\
\text { business relationships, not bias, avoiding conflict of } \\
\text { interest, complying with the most current regulation, } \\
\text { and avoiding discredit conduct. }\end{array}$ \\
\hline
\end{tabular}

Table 5 depicts the accountant's professional identity and the process of its formation. In general, an accountant should have multiple identities, namely good responsibility to the client and capable of figuring out client financial reporting issues. Furthermore, they must avoid the misconduct that breaks the law and ethics as an accountant. The highlighted process of identity development among accountants is joining to the accountant professional communities. Similar to the teachers, the accountant also has group level identities based on the early career and experienced accountant.

The assumption of identity theory, previous findings in the teacher's professional identity, and the accountant's professional identity bring the broad concept of the accounting teacher professional identity and its development. The general concept of accounting professional identity follows the identity theory that there are four components, such as input, identity standard, comparator, and input. From those four components, the identity standard needs to be looked deeper. The identity standard for Indonesian accounting teachers professional identity is absorbed from Indonesian law, teacher professional identity, and accountant professional identity. Besides the obligated four competencies (pedagogy, personal, social, and professional), the accounting teacher needs to have identities and accountant identities.

The identities among accounting teachers need to be broken down into three stages. First of all, accounting pre-service teachers should have identities such as having capability as a friend for their peers and students in the school training, being an active student while practicing, and interactive trainee. As a part of the accountant educator, they encourage to join the communities of a junior accountant or accountant teacher socialization even only as an observer. To develop these identities, they need to join 
more practice teaching activities, broaden networks by joining communities, produce academic writing about the accounting education, and activate to ask the senior teachers regarding their experiences.

The second stage is beginner teachers. The most feeling that arises among this group is anxiety because of the identity shifting and the discursive situation. The beginner teacher worries about the learning situation they will face in the school that may be different from the learning situation they learnt at campus. However, the most important identity that must be mastered by the early career teachers is the willingness to bring students not to have the same difficulties in learning particular material as they felt when they are in school or university. They strive in many ways to ensure their students understand more than them when they do in school. The joining communities both in the teacher and an accountant profession are the only stated way to develop accounting teacher identity in this stage.

The last stage is in the experienced teachers. It does not mean that treating these teachers is easier than both pre-service and beginner teachers. The maturity of experienced teachers requires them to have all the needed identities that bring professionalism among them. The teachers should have a role as an artist to attract students to learn happily, be mother or father in school, promoter, wise judge, and accept advice and criticism from the students and colleagues. Furthermore, they must have the capability to assimilate the changes in accounting standards and the social context of teaching in the rapid change of technology. As accounting teachers, the experienced teachers should be straightforward and honest in all professional and business relationships, not bias, avoiding conflict of interest, complying with the most current regulation, and avoiding discredit conduct. Besides broadening joining the professional community of accountant, teacher, and accountant teachers, professional identity development requires the teacher's self-action, namely playing drama and holding the idealism in teaching accountancy. Furthermore, experienced teachers' rapid change in technology must be adopted because the digital era pushes the re-examination of the professional identity among teachers, which is pursuing teachers to be more innovative [72]. Even the professionalism among teachers can be traced by reviewing their posts on twitter [67].

\section{Conclusions}

The works of literature in accounting professional identity are taken from the structural symbolic interactionism, identity theory, teacher and accountant professional identity studies, and the education law regarding teacher professionalism. In the Indonesian education system, the professional identity is not yet noticed; thus, the meaning of accounting teacher professionalism can be bias. The identity theory guides us on how to develop a professional identity in accounting teachers and their components. The most important but unavailable part of identity formation namely the identity standard for accounting teachers is essential to be studied even though the input (teachers' perception of their capability and the society) is also essential. The proposed identity standard in this study absorbs the teacher's professional identity as general and the accountant professional identity that consists of a set of behavior. The accounting teacher professional identity formation needs to be divided into three stages, namely pre-service, early-career teacher, and experienced teacher. Each stage has particular challenges and peripheral condition that needs special treatment. The professional identity development is a long journey of professional identity among accounting teachers. They must be trained well in pre-service until an experienced one. However, in every stage, the highlighted strategy is joining the professional community. Teacher should join particular communities in accordance with his/her phase of teacher life journey. Last but not least, the Indonesian teacher education program needs to consider the development of professional identity among accounting teachers.

\section{REFERENCES}

[1] J. Y. Hong, "Pre-service and beginning teachers' professional identity and its relation to dropping out of the profession,” Teach. Teach. Educ., vol. 26, no. 8, pp. 1530 1543, Nov. 2010.

[2] D. J. Osman and J. R. Warner, "Measuring teacher motivation: The missing link between professional development and practice,” Teach. Teach. Educ., vol. 92, p. 103064, 2020.

[3] Y. Zhu, "Individual Behavior: In-role and Extra-role,” Int. J. Bus. Adm., vol. 4, no. 1, pp. 23-27, 2013.

[4] A. Somech and A. Drach-Zahavy, "Understanding extra-role behavior in schools: The relationships between job satisfaction, sense of efficacy, and teachers' extra-role behavior,” Teach. Teach. Educ., vol. 16, no. 5, pp. 649-659, 2000.

[5] Undang-Undang, Undang-Undang Republik Indonesia Tentang Guru Dan Dosen, no. March. Indonesia, 2005, pp. 25-27.

[6] E. Insulander, D. Brehmer, and A. Ryve, “Teacher agency in professional development programmes - A case study of professional development material and collegial discussion," Learn. Cult. Soc. Interact., vol. 23, no. February, p. 100330, 2019.

[7] T. Atapattu, M. Thilakaratne, R. Vivian, and K. Falkner, "Detecting cognitive engagement using word embeddings within an online teacher professional development community," Comput. Educ., vol. 140, no. May, p. 103594, 2019. 
[8] H. N. Perera, H. Granziera, and P. McIlveen, "Profiles of teacher personality and relations with teacher self-efficacy, work engagement, and job satisfaction," Pers. Individ. Dif., vol. 120, no. April 2017, pp. 171-178, 2018.

[9] P. Dolton, O. Marcenaro, R. De, and P.-W. She, GLOBAL TEACHER STATUS INDEX 2018 This Report presents the results of a large scale public survey of 35 countries on Teachers and Educational Systems. A Global Teacher Status Index is reported. Varkey Foundation, 2018.

[10] S. Wolf and M. E. Peele, "Examining sustained impacts of two teacher professional development programs on professional well-being and classroom practices,” Teach. Teach. Educ., vol. 86, p. 102873, 2019.

[11] B. Fauth et al., "The effects of teacher competence on student outcomes in elementary science education: The mediating role of teaching quality," Teach. Teach. Educ., vol. 86, p. 102882, 2019.

[12] L. Uiterwijk-Luijk, M. Krüger, B. Zijlstra, and M. Volman, “Teachers' role in stimulating students' inquiry habit of mind in primary schools," Teach. Teach. Educ., vol. 86, p. 102894, 2019.

[13] S. J. Schwartz, K. Luyckx, and V. L. Vignoles, Handbook of Identity Theory and Research. 2011.

[14] M. Kaur, "Exploring teachers professional identity: Role of teacher emotions in developing professional identity," Biosci. Biotechnol. Res. Commun., vol. 11, no. 4, pp. 719726, 2018.

[15] J. Y. Hong, “Pre-service and beginning teachers' professional identity and its relation to dropping out of the profession,” Teach. Teach. Educ., vol. 26, no. 8, pp. 1530 1543, 2010.

[16] D. M. Gibson, C. T. Dollarhide, and J. M. Moss, "Professional identity development: A grounded theory of transformational tasks of new counselors," Couns. Educ. Superv., vol. 50, no. September, pp. 21-39, 2010.

[17] V. Lentillon-Kaestner, E. Guillet-Descas, G. Martinent, and V. Cece, "Validity and reliability of questionnaire on perceived professional identity among teachers (QIPPE) scores,” Stud. Educ. Eval., vol. 59, no. September, pp. 235243, 2018.

[18] S. Nyström, “The dynamics of professional identity formation: Graduates' transitions from higher education to working life,” Vocat. Learn., vol. 2, no. 1, pp. 1-18, 2009.

[19] L. Losano, D. Fiorentini, and M. Villarreal, "The development of a mathematics teacher's professional identity during her first year teaching," J. Math. Teach. Educ., vol. 21, no. 3, pp. 287-315, 2018.

[20] C. D. Nguyen, "Metaphors as a window into identity: A study of teachers of English to young learners in Vietnam," System, vol. 60, pp. 66-78, 2016.

[21] H. Colliander, "The experienced newcomer - The (trans)forming of professional teacher identity in a new landscape of practices,” Teach. Teach. Educ., vol. 69, pp. 168-176, 2018.

[22] A. Devos, "New teachers, mentoring and the discursive formation of professional identity," Teach. Teach. Educ., vol. 26, no. 5, pp. 1219-1223, 2010.
[23] J. Ballantyne and K. Zhukov, "A good news story: Early-career music teachers' accounts of their 'flourishing' professional identities,” Teach. Teach. Educ., vol. 68, pp. 241-251, 2017.

[24] S. Imroatun and Sukirman, "Pengaruh Lingkungan Kerja, Kompensasi Kerja, Dan Motivasi Kerja Terhadap Kinerja Guru Ekonomi/ Akuntansi Di Sma Negeri Se-Kabupaten Wonosobo,” Econ. Educ. Anal. J., vol. 5, no. 1, pp. 181-194, 2016.

[25] M. Ansori, S. Arief, and S. Sukirno, "Profesionalisme Guru Akuntansi Pasca Sertifikasi,” J. Pendidik. Ekon. dan Bisnis, vol. 5, no. 1, p. 107, 2017.

[26] A. Mukhadis, A. B. N. Rahma Putra, A. M. Nidhom, A. Dardiri, and H. Suswanto, "The Relevance of Vocational High School Program with Regional Potency Priority in Indonesia,” J. Phys. Conf. Ser., vol. 1028, no. 1, 2018.

[27] N. Mockler and J. Sachs, Rethinking educational practice through reflexive inquiry: essays in honour of Susan Groundwater-Smith. 2011.

[28] C. Beauchamp and L. Thomas, "Understanding teacher identity: An overview of issues in the literature and implications for teacher education," Cambridge J. Educ., vol. 39, no. 2, pp. 175-189, 2009.

[29] L. Leigh, “' Of course I have changed!’: A narrative inquiry of foreign teachers' professional identities in Shenzhen, China,” Teach. Teach. Educ., vol. 86, p. 102905, 2019.

[30] J. Hubbard, “K-6 pre-service teachers' emerging professional identities as social studies educators,” J. Soc. Stud. Res., 2018.

[31] D. Beijaard, P. C. Meijer, and N. Verloop, "Reconsidering research on teachers' professional identity," Teach. Teach. Educ., vol. 20, no. 2, pp. 107-128, 2004.

[32] N. Hooley, "Establishing Professional Identity: Narrative as Curriculum for Pre-Service Teacher Education,” Aust. J. Teach. Educ., vol. 32, no. 1, 2007.

[33] F. Patrick and A. McPhee, "Professional identity," Rev. linfirmiere, vol. 42, no. 2.3, 2014.

[34] F. Hanna, R. Oostdam, S. E. Severiens, and B. J. H. Zijlstra, "Assessing the professional identity of primary student teachers: Design and validation of the Teacher Identity Measurement Scale,” Stud. Educ. Eval., vol. 64, no. October 2019, p. 100822, 2020.

[35] M. Verkuyten, J. Thijs, and N. Gharaei, “Discrimination and academic (dis)engagement of ethnic-racial minority students: a social identity threat perspective," Soc. Psychol. Educ., vol. 22, no. 2, pp. 267-290, 2019.

[36] S. Stryker, “Traditional Symbolic Interactionism, Role Theory, and Structural Symbolic Interactionism: The Road to Identity Theory,” Handb. Sociol. Theory, pp. 211-231, 2002.

[37] P. J. Burke and Jan E. Stets P, Identity Theory (Google eBook). 2009.

[38] I. Timoštšuk and A. Ugaste, “Student teachers’ professional identity,” Teach. Teach. Educ., vol. 26, no. 8, pp. 1563-1570, 2010.

[39] A. Steadman, H. Kayi-Aydar, and S. M. Vogel, "From 
college composition to ESL: Negotiating professional identities, new understandings, and conflicting pedagogies," System, vol. 76, pp. 38-48, 2018.

[40] M. Ruohotie-Lyhty and J. Moate, "Who and how? Preservice teachers as active agents developing professional identities,” Teach. Teach. Educ., vol. 55, pp. 318-327, 2016.

[41] T. K. A. Dang, "Identity in activity: Examining teacher professional identity formation in the paired-placement of student teachers," Teach. Teach. Educ., vol. 30, no. 1, pp. 47-59, 2013.

[42] L. de A. D. Rodrigues, E. de Pietri, H. S. Sanchez, and K. Kuchah, "The role of experienced teachers in the development of pre-service language teachers' professional identity: Revisiting school memories and constructing future teacher selves,” Int. J. Educ. Res., vol. 88, no. October 2017, pp. 146-155, 2018.

[43] M. Izadinia, “A closer look at the role of mentor teachers in shaping preservice teachers’ professional identity,” Teach. Teach. Educ., vol. 52, pp. 1-10, 2015.

[44] J. H. E. Assen, H. Koops, F. Meijers, H. Otting, and R. F. Poell, "How can a dialogue support teachers' professional identity development? Harmonising multiple teacher I-positions," Teach. Teach. Educ., vol. 73, pp. 130-140, 2018.

[45] M. Arvaja, "Building teacher identity through the process of positioning," Teach. Teach. Educ., vol. 59, pp. 392-402, 2016.

[46] D. Tsybulsky and Y. Muchnik-Rozanov, “The development of student-teachers' professional identity while team-teaching science classes using a project-based learning approach: A multi-level analysis,” Teach. Teach. Educ., vol. 79, pp. 48-59, 2019.

[47] Y. Kao and S. Lin, "Constructing a Structural Model of Teachers' Professional Identity,” Asian J. Manag. Sci. ..., vol. 4, no. January, pp. 69-81, 2015.

[48] S. Moola, "Crafting, Constructing and Developing a Nurses' Professional Identity Scale (NPIS),” Glob. J. Health Sci., vol. 9, no. 7, p. 21, 2017.

[49] F. Hanna, R. Oostdam, S. E. Severiens, and B. J. H. Zijlstra, "Primary student teachers' professional identity tensions: The construction and psychometric quality of the professional identity tensions scale,” Stud. Educ. Eval., vol. 61, no. January, pp. 21-33, 2019.

[50] Y. Zhang, S. T. Hawk, X. Zhang, and H. Zhao, “Chinese preservice teachers' professional identity links with education program performance: The roles of task value belief and learning motivations," Front. Psychol., vol. 7, no. APR, pp. 1-12, 2016.

[51] W. Wasityastuti, Y. P. Susani, Y. S. Prabandari, and G. R. Rahayu, "Correlation between academic motivation and professional identity in medical students in the Faculty of Medicine of the Universitas Gadjah Mada Indonesia,” Educ. Medica, vol. 19, no. 1, pp. 23-29, 2018.

[52] H. Jonker, V. März, and J. Voogt, “Teacher educators' professional identity under construction: The transition from teaching face-to-face to a blended curriculum," Teach. Teach. Educ., vol. 71, pp. 120-133, 2018.
[53] L. Bennett, "Social media, academics' identity work and the good teacher,” Int. J. Acad. Dev., vol. 22, no. 3, pp. 245-256, 2017.

[54] X. Huang, J. C. Lee, and X. Yang, "What really counts ? Investigating the effects of creative role identity and self-ef fi cacy on teachers ' attitudes towards the implementation of teaching for creativity," Teach. Teach. Educ., vol. 84, pp. 57-65, 2019.

[55] N. Setiawan and D. Setyorini, “Audit Kinerja Guru Akuntansi Bersertifikat Di Smk Negeri-2 Kutoarjo Purworejo,” J. Pendidik. Akunt. Indones., vol. VII, no. 2, pp. 85-96, 2009.

[56] M. B. Harari, H. R. Parola, C. J. Hartwell, and A. Riegelman, "Literature searches in systematic reviews and meta-analyses: A review, evaluation, and recommendations," J. Vocat. Behav., vol. 118, no. December 2019, p. 103377, 2020.

[57] S. F. Akkerman and P. C. Meijer, "A dialogical approach to conceptualizing teacher identity,” Teach. Teach. Educ., vol. 27, no. 2, pp. 308-319, 2011.

[58] R. Jaspal and G. M. Breakwell, In Reply: BEHAVIOUR THERAPY, vol. 111, no. 479. 2014.

[59] H. W. Lim, “Concept maps of Korean EFL student teachers' autobiographical reflections on their professional identity formation,” Teach. Teach. Educ., vol. 27, no. 6, pp. 969-981, 2011.

[60] R. Mosvold and R. Bjuland, "Positioning in identifying narratives of/about pre-service mathematics teachers in field practice,” Teach. Teach. Educ., vol. 58, pp. 90-98, 2016.

[61] D. F. Macías Villegas, W. Hernández Varona, and A. Sánchez Gutiérrez, “Student teachers’ identity construction: A socially-constructed narrative in a second language teacher education program,” Teach. Teach. Educ., vol. 91, pp. 1-10, 2020.

[62] E. R. Yuan, "The dark side of mentoring on pre-service language teachers' identity formation,” Teach. Teach. Educ., vol. 55, pp. 188-197, 2016.

[63] M. Ruohotie-Lyhty, "Struggling for a professional identity: Two newly qualified language teachers' identity narratives during the first years at work," Teach. Teach. Educ., vol. 30, no. 1, pp. 120-129, 2013.

[64] J. Gujarati, “An 'inverse’ relationship between mathematics identities and classroom practices among early career elementary teachers: The impact of accountability,” J. Math. Behav., vol. 32, no. 3, pp. 633-648, 2013.

[65] M. Connolly, M. Hadfield, Y. Barnes, and J. Snook, “The accommodation of contested identities: The impact of participation in a practice-based masters programme on beginning teachers' professional identity and sense of agency,” Teach. Teach. Educ., vol. 71, pp. 241-250, 2018.

[66] T. S. C. Farrell, "Exploring the professional role identities of experienced ESL teachers through reflective practice," System, vol. 39, no. 1, pp. 54-62, 2011.

[67] J. P. Carpenter, R. Kimmons, C. R. Short, K. Clements, and M. E. Staples, "Teacher identity and crossing the professional-personal divide on twitter," Teach. Teach. Educ., vol. 81, pp. 1-12, 2019. 
[68] S. E. Hamilton, "Exploring professional identity: The perceptions of chartered accountant students,” Br. Account. Rev., vol. 45, no. 1, pp. 37-49, 2013.

[69] F. Brouard, M. Bujaki, S. Durocher, and L. C. Neilson, "Professional Accountants' Identity Formation: An Integrative Framework,” J. Bus. Ethics, vol. 142, no. 2, pp. 225-238, 2017.

[70] L. D. Parker and S. Warren, "The presentation of the self and professional identity: countering the accountant's stereotype,” Enerald Insight, no. Unit 07, pp. 1-5, 2017.

[71] S. Dellaportas, L. Perera, S. Gopalan, and B. Richardson, "Implications of a Fragile Professional Identity on Role Behavior: An Exploratory Case of an Accountant Fraudster," Eur. Account. Rev., vol. 28, no. 4, pp. 659-679, 2019.

[72] O. Avidov-Ungar and A. Forkosh-Baruch, "Professional identity of teacher educators in the digital era in light of demands of pedagogical innovation,” Teach. Teach. Educ., vol. 73, pp. 183-191, 2018.

[73] Wambugu, P. W. (2018). Massive open online courses (MOOCs) for professional teacher and teacher educator development: A case of TESSA MOOC in Kenya. Universal Journal of Educational Research, 6(6), 1153-1157. https://doi.org/10.13189/ujer.2018.060604

[74] Rellin, R., Pataueg, R. J., Pineda, R., Sabalo, J., Siazon, M. A., Tindowen, D. J., \& Catacutan, K. J. (2020). A study on the accounting education culture of the university of Saint Louis, Philippines. Universal Journal of Educational Research, 8(7), 2809-2815. https://doi.org/10.13189/ujer.2 020.080707

[75] Farrell, T. S. C. (2011). Exploring the professional role identities of experienced ESL teachers through reflective practice. System, 39(1), 54-62. https://doi.org/10.1016/j.sys tem.2011.01.012 